Horticulturae 2015, 1, 44-54; doi:10.3390/horticulturae1010044

Article

\title{
Comparative Leaf Phenology of White Oak and Northern Red Oak
}

\section{Jayesh B. Samtani ${ }^{1, *}$, James E. Appleby ${ }^{2}$ and John B. Masiunas ${ }^{3}$}

1 Hampton Roads AREC, Department of Horticulture, Virginia Polytechnic Institute and State University, 1444 Diamond Springs Road, Virginia Beach, VA 23455, USA

2 Department of Natural Resources and Environmental Sciences, University of Illinois at Urbana-Champaign, 1102 S. Goodwin Avenue, Urbana, IL 61801, USA;

E-Mail: jappleby@illinois.edu

3 Department of Crop Sciences, University of Illinois at Urbana-Champaign, $1201 \mathrm{~W}$. Gregory Drive, Urbana, IL 61801, USA; E-Mail: masiunas@illinois.edu

* Author to whom correspondence should be addressed; E-Mail: jsamtani@vt.edu.

Academic Editors: Douglas D. Archbold and Linda Chalker-Scott

Received: 8 September 2015 / Accepted: 3 December 2015 / Published: 10 December 2015

\begin{abstract}
In the landscape, loss of interveinal tissue in developing leaves (leaf tatters) is common for white oak (Quercus alba L.), but not northern red oak (Quercus rubra L.). Previous research identified the cause of leaf tatters, as exposure of unfolding leaves, to low concentrations of chloroacetanilide herbicides. Both white oak and northern red oak were injured by these herbicides at the leaf unfolding stage. Reports from landowners suggest white oak is injured more often than red oak, leading us to theorize that white and northern red oak leaves emerge at different times, and white oaks were more likely to be at the leaf unfolding stage when chloroacetanilide herbicides are applied. A study of comparative leaf phenology of white and northern red oak was done at three sites in Urbana, IL. Identifying oak pairs was challenging, and at each location, four to six paired mature white oak and northern red oak trees were used to observe phenological events. Key development stages (swollen bud, leaf unfolding, or fully expanded leaf stages) were considered to have occurred when reached by greater than $50 \%$ of the canopy. Northern red oak expanded leaf stage occurred earlier when compared to white oak. Time between phenological events was similar for both species. Although northern red oak leaves emerged earlier, there was a range of emergence times within short distances. Difference
\end{abstract}


between locations illustrates the problem in predicting tree phenology even among populations a few kilometers apart. Leaf phenology alone does not explain leaf tatters, and other factors including distribution differences in oak species must explain landowner observations of tree injury. There was a strong correlation between growth phases of the two oak species with cumulative growing degree days, cumulative rainfall, and day length.

Keywords: Quercus alba; Quercus rubra; herbicide drift; leaf unfolding stage

\section{Introduction}

Previous research found that loss of interveinal tissue (leaf tatters) is caused by exposure of white or northern red oak seedlings to low concentrations of chloroacetanilide herbicides, at the leaf unfolding stage $[1,2]$. Swollen bud and expanded leaf stages are not susceptible to chloroacetanilide herbicides. Chloroacetanilides strongly inhibit the synthesis of very-long chain fatty acids (VLCFA) of C20, 22, and 24 [3]. VLCFA (C20 to C34) are essential for derivation of plasma membranes, and predominant cuticular wax constituents such as primary and secondary alcohols, aldehydes, alkanes, ketones, and esters [4,5]. Direct consequences lead to loss of cell integrity, and plant death.

In controlled studies, northern red oaks were slightly more susceptible to chloroacetanilides than white oaks [2]. Interestingly, in the landscape, leaf tatters are observed more consistently on white oak when compared to northern red oak. In the Midwestern U.S., farms, woodlands, and residential dwellings are often intermingled and in close proximity to agricultural fields, possibly contributing to leaf tatters injury. Oaks of all ages are affected by leaf tatters. Tatters can affect part of, or the whole canopy, resulting in a decline in aesthetic value of the oaks, and also possibly making trees susceptible to other stresses. Oaks affected by leaf tatters one year may or may not be affected by tatters in subsequent years.

Trees and shrubs native to temperate zones undergo rhythmic changes in growth and dormancy that are synchronized and controlled by seasonal changes, including day length and temperature [6]. Phenological or life cycle events reflect differences in adaptive strategies of a species to exploit favorable periods, and to allocate photosynthetic products for growth and reproduction $[7,8]$. For northern hardwood species, leaf phenology also may be important for shade tolerance [9]. Microclimatic conditions and rainfall influence phenological development [10]. An understanding of the seasonal behavior of trees is of great importance to nurserymen, landscapers, entomologists, ecologists and plant physiologists $[11,12]$, and for guiding timing of herbicide applications.

Phenotypic variation may affect oak developmental timing and response to herbicides. Red and white oaks are propagated from seed, and likely are genetically diverse. Genetic or phenotypic variation of red and white oak have not been reported in the literature, but phenotypic variation occurs in other oak species. Previous studies observed variation in herbicide response within oak species [1,2]. Phenological differences among individual trees, and among populations of Valonia oak (Quercus ithaburensis Decne) in northern Israel, have been attributed to genetic variation [13]. In France, genetic variation among individual trees of Holm oak (Quercus ilex) was reported [14]. Phenological differences between individual trees of English oak (Quercus robur L.) were also pronounced and consistent [15]. 
Variation in timing of leaf opening between species within years, and between years for some species, is not uncommon [16,17]. Individual variation in tree phenology can be attributed in part to physical differences among sites such as neighboring vegetation, and effects of animals [18]. Phenological development may have to be quantified for individual populations of oaks if used to time herbicide applications.

We hypothesize that phenology of white and northern red oak leaf emergence differs, and white oaks are more frequently at a susceptible growth stage when adjacent agricultural fields are treated with chloroacetanilide herbicides. Objectives of this study were to: (1) determine relative timing of white and northern red oak development from swollen buds to the fully mature leaf stages; (2) determine if susceptibility of white oak to leaf tatters in the landscape is related to leaf phenological development; (3) and correlate the phenological events of white and red oak to a degree day model, day length, and cumulative rainfall.

\section{Experimental Section}

A comparative leaf phenology study of white and northern red oak was done at three sites in Urbana, IL: the University of Illinois Arboretum $\left(40^{\circ} 05^{\prime} 49.29^{\prime} \mathrm{N}, 88^{\circ} 13^{\prime} 01.55^{\prime \prime} \mathrm{W}\right.$, elevation $\left.226 \mathrm{~m}\right)$, Crystal Lake Park $\left(40^{\circ} 07^{\prime} 14.90^{\prime} \mathrm{N}, 88^{\circ} 12^{\prime} 44.62^{\prime \prime} \mathrm{W}\right.$, elevation $\left.215 \mathrm{~m}\right)$, and Illini Grove $\left(40^{\circ} 07^{\prime} 51.96^{\prime} \mathrm{N}\right.$, $88^{\circ} 08^{\prime} 44.32^{\prime \prime} \mathrm{W}$, elevation $212 \mathrm{~m}$ ). All of these sites, although not adjacent to a field, are within a distance of 8 to $11 \mathrm{~km}$ from grower fields. The University of Illinois Arboretum, established in 1990, has 4 ha of naturalized woodland with $0 \%$ to $5 \%$ slope, and soil is composed of $58 \%$ Dana silt loam, $24 \%$ Drummer silty clay loam, and 18\% Flanagan silt loam [19]. This site has a varied collection of hardwoods and conifers. The 36 ha Crystal Lake Park, established in 1907, is an old recreational park in Urbana, and includes 24 ha of wooded area. Land at this site has a 0 to $2 \%$ slope, and is composed of predominately Sawmill silty clay loam soil. Illini Grove, a 2 ha area, was established in 1868 for studies in forestry, by the University of Illinois. It contains a mix of mature oaks (Quercus spp.), hickory (Carya spp.), and larch (Larix spp.). Soil at this site is a 95\% Catlin silt loam, and the land has a 2 to $5 \%$ slope. All of these sites were chosen for the presence of mature, native, mixed stands of white oak and northern red oak in urban and semi-urban areas, and the ability to view the entire canopy of the trees. Proximity of these sites to the university ensured regular observations of phenological development.

\subsection{Tree Characterization}

At each site, a white oak tree was paired with a northern red oak tree. Canopy width, the diameter at breast height ( $\mathrm{dbh}$ - measured at $1.4 \mathrm{~m}$ height), and the tree height, were taken into consideration when determining a pair. At all locations, distance between the white and northern red oak forming a pair were measured, and ranged from 8.0 to $30.8 \mathrm{~m}$. When selecting a pair, we minimized differences in height and dbh between the two oak species. A linear Lufkin Nubian tape (Forestry Suppliers Inc., Jackson, MS, USA) was used to measure dbh, and tree heights were measured using a Suunto clinometer (Suunto Instruments, Forestry Suppliers Inc., Jackson, MS, USA). Phenological observations were made on four pairs of oaks at the Arboretum, five pairs at Crystal Lake Park, and six pairs at Illini Grove. 


\subsection{Phenological Development}

Observations were made every 3 to $4 \mathrm{~d}$ beginning 11 April in 2006, and 26 March in 2007. We recorded occurrence of 50\% swollen bud, 50\% leaves unfolding, and 50\% fully expanded leaf growth stages for the canopy [20]. These events were expressed in Julian days. When tree canopy showed greater than 50\% leaves unfolding, observations were stopped. Trees were viewed each time from the same position in the landscape. Viewing positions were chosen so the entire or most of the tree canopy was visible. When observation date preceded or exceeded the date of a phenological event, the date was extrapolated [13]. Duration between these phenological events were termed phenological phases and were expressed in number of days; from 50\% swollen buds to $50 \%$ leaves unfolding (phase 1) and from 50\% leaves unfolding to 50\% fully expanded leaves (phase 2). An oak in phase 2 is highly susceptible to leaf tatters.

Climate data (daily maximum, minimum, and average temperatures; day length, cumulative precipitation) were used to identify environmental conditions during phenological events, and explain differences between years. Climatic measurements were from the Illinois Water Survey weather station at $40^{\circ} 05^{\prime} 02.85^{\prime \prime} \mathrm{N}, 88^{\circ} 14^{\prime} 27.94^{\prime \prime} \mathrm{W}$ (approximately $3 \mathrm{~km}$ east of the Arboretum). Phenological data were correlated to the climate data to determine possible associations.

\subsection{Data Analysis}

Mean tree heights and $\mathrm{dbh}$ for white and red oak at each location, were subject to paired $t$-test at alpha $=0.05$ (Table 1). Experimental design of the study was a repeated measure with locations, species, growth stage, and years as factors. The species were the treatments in the study (between subject factors). The three growth stages (within subject factor) were the repeated measure, and individual trees were the replications. Replications, i.e., individual trees, were nested within location and species. Data were analyzed with PROC MIXED in SAS (release 8.02; SAS Institute Inc., Cary, $\mathrm{NC}, \mathrm{USA}$ ) looking at the significance of the four-way interaction first, and the three-way interactions, in the event, the four-way interactions were not significant. Letters for mean separation were assigned using a macro "PDMIX 800" [21]. Compound symmetric, autoregressive, and unstructured covariance were compared, and unstructured covariance produced the best fit.

Table 1. Means of tree height in meters, and diameter at breast height (dbh) in $\mathrm{cm}$, of white and northern red oak trees at the Arboretum, Crystal Lake Park, and Illini Grove, in Urbana, IL in 2006 and 2007.

\begin{tabular}{|c|c|c|c|c|c|}
\hline \multirow{3}{*}{ Location } & \multirow{3}{*}{ No. of Pairs } & \multicolumn{2}{|c|}{2006} & \multicolumn{2}{|c|}{2007} \\
\hline & & Red Oak & White Oak & Red Oak & White Oak \\
\hline & & \multicolumn{4}{|c|}{ Height (m)/dbh cm } \\
\hline Arboretum & 4 & $23.4 * / 57.1 * \mathrm{a}$ & $17.7 * / 49.0 *$ & $24.3 * / 58.6 *$ & $18.5 * / 50.3 *$ \\
\hline Crystal Lake & 5 & $23.7 / 75.9$ & $21.6 / 69.3$ & $23.9 / 77.7$ & $22.5 / 71.6$ \\
\hline Illini Grove & 6 & $29.6 / 61.0$ & $29.9 / 59.7$ & $31.4 / 62.3$ & $31.5 / 60.7$ \\
\hline
\end{tabular}


Phenological stages were related to climate conditions (degree-day, cumulative rainfall, and day length) using Pearson product-moment correlation coefficient (r) in SAS.

Effect of degree days was determined using the equation:

$$
\text { Degree-days }=\sum\left(\mathrm{T}_{\text {mean }}-\mathrm{T}_{\min }\right)
$$

where $\mathrm{T}_{\text {mean }}$ is the average daily temperature, and $\mathrm{T}_{\min }$ was the minimum growth temperature. Minimum temperatures for growth were $4{ }^{\circ} \mathrm{C}$ for northern red oak, and $1{ }^{\circ} \mathrm{C}$ for white oak [22].

\section{Results and Discussion}

\subsection{Tree Characterization}

Despite our efforts to minimize differences in height and dbh, mean height and dbh of red oak trees was greater compared to white oak trees, at the Arborteum (Table 1). For the other two sites, there were no differences in dbh and mean heights between the two oak species.

\subsection{Phenological Development}

Location, species, and growth stage interacted to affect leaf phenology. Swelling of buds occurred at the same time. At Crystal Lake Park and Illini Grove, northern red oak leaf unfolding and expanded leaf stages occurred earlier compared to white oak (Table 2). At the Arboretum, only the expanded leaf stage occurred earlier on northern red oak compared to white oak. The difference between locations illustrates the problem in predicting tree phenology even among populations $3 \mathrm{~km}$ apart. Site and tree differences chronologies were previously found for red and white oak [23].

Table 2. Effect of the three-way, location, species, and growth stage interactions, on phenological events (in Julian days) of white and red oak species. Results were averaged over years.

\begin{tabular}{llccc}
\hline \multirow{2}{*}{ Location } & \multirow{2}{*}{ Species } & \multicolumn{3}{c}{ Growth Stage } \\
\cline { 3 - 5 } & & Swollen Bud & Leaf Unfolding & Expanded Leaf \\
\cline { 2 - 5 } Arboretum & Red & $101.6 \mathrm{f}^{\mathbf{a}}$ & $111.6 \mathrm{de}$ & $124.4 \mathrm{~b}$ \\
\cline { 2 - 5 } & White & $96.5 \mathrm{fg}$ & $113.3 \mathrm{~cd}$ & $130.8 \mathrm{a}$ \\
\hline \multirow{2}{*}{ Crystal Lake } & Red & $94.6 \mathrm{~g}$ & $109.4 \mathrm{e}$ & $126.2 \mathrm{~b}$ \\
\cline { 2 - 5 } & White & $97.6 \mathrm{fg}$ & $114.9 \mathrm{c}$ & $129.7 \mathrm{a}$ \\
\hline \multirow{2}{*}{ Illini Grove } & Red & $100.4 \mathrm{f}$ & $110.1 \mathrm{e}$ & $125.5 \mathrm{~b}$ \\
\cline { 2 - 5 } & White & $101.7 \mathrm{f}$ & $113.5 \mathrm{~cd}$ & $130.1 \mathrm{a}$ \\
\hline
\end{tabular}

a Means with the same letter across and down columns are not significantly different at $p \leq 0.05$, using PROC MIXED.

The leaf unfolding stage is the most susceptible stage to chloroacetanilides. The leaf unfolding stage occurred earlier on northern red oak when compared to white oak (Table 3). Thus, the northern red oak trees are in the chloroacetanilide-susceptible leaf unfolding stage and enter the tolerant expanded leaf stage earlier when compared to white oak. Pre-emergence applications of chloroacetanilide herbicides are applied to corn and soybeans over an extended period of time. Small differences in developmental 
timing probably do not fully explain field observations of less injury of northern red oak compared to white oak. Range, location, and proximity to agricultural fields may play a role too. Distribution range of northern red oak is more northern when compared to white oak, and it is less common in the Corn Belt $[11,23,24]$.

Differences in phenological events between years relates to environmental conditions. In 2007, warmer air temperatures in the 80 to 90 Julian d period promoted earlier bud swelling, when compared to 2006 (Figure 1; Table 3). Maximum air temperature on Days 84 and 86 in 2007 reached $26.7^{\circ} \mathrm{C}$, setting a new record high for the 84th Julian d [25]. Warm temperatures during the 60 to 90 Julian $d$ period promoted early and rapid development of the red and white oaks, leaving them vulnerable to injury from cold temperatures during the 94 to 100 Julian d period [25]. An early budburst often exposes trees to a higher risk of frost damage [6]. Extended cold weather in the 91 to 120 Julian $d$ period caused damage to apple and peach trees across Illinois [25]. During this cold period, air temperatures were at or below $0{ }^{\circ} \mathrm{C}$ for $110 \mathrm{~h}$ [25]. Some newly-emerged flowers and vegetative buds on the oaks were killed by cold temperatures. This lead to a delay in trees reaching the $50 \%$ leaf unfolding growth stage as compared with 2006. Earliness of the leaf unfolding stage in the 90 to 120 Julian d period in 2006 can be attributed to near record temperatures that made it one of the warmest Aprils on record [25].

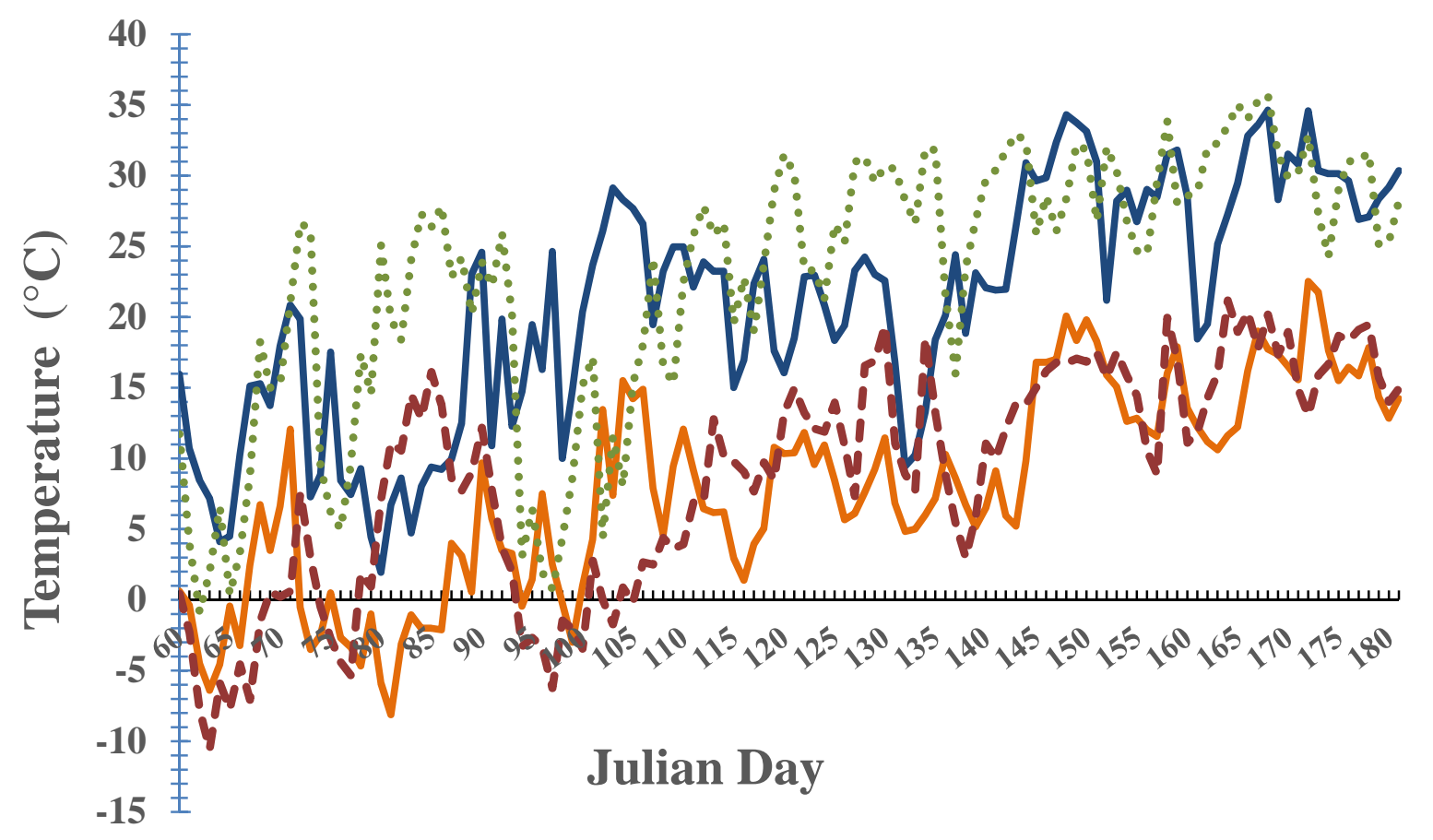

$$
\begin{aligned}
& -2006 \text { Temp. Max. } \_2006 \text { Temp. Min. } \\
& \ldots . .2007 \text { Temp. Max. }---2007 \text { Temp. Min. }
\end{aligned}
$$

Figure 1. Maximum and minimum temperatures in Urbana, IL, from 60 to 180 Julian days. The $0{ }^{\circ} \mathrm{C}$ line is indicated. Data source: Illinois State Water Survey. 
Table 3. Effect of the three-way, species, growth stage, and year interactions on phenological events (in Julian days) of white and northern red oak species. Results were averaged over location.

\begin{tabular}{ccccc}
\hline \multirow{2}{*}{ Year } & \multirow{2}{*}{ Species } & \multicolumn{3}{c}{ Growth Stage } \\
\cline { 3 - 5 } & & Swollen Bud & Leaf Unfolding & Expanded Leaf \\
\cline { 3 - 5 } & & & Julian d \\
\hline \multirow{2}{*}{2006} & Red & $101.0 \mathrm{~h}^{\mathbf{a}}$ & $105.3 \mathrm{~g}$ & $123.2 \mathrm{c}$ \\
\cline { 2 - 5 } & White & $105.6 \mathrm{~g}$ & $109.2 \mathrm{f}$ & $128.1 \mathrm{~b}$ \\
\hline \multirow{2}{*}{2007} & Red & $96.8 \mathrm{i}$ & $115.4 \mathrm{e}$ & $127.6 \mathrm{~b}$ \\
\cline { 2 - 5 } & White & $91.5 \mathrm{i}$ & $118.6 \mathrm{~d}$ & $132.3 \mathrm{a}$ \\
\hline
\end{tabular}

a Means with the same letter across and down columns are not significantly different at $p \leq 0.05$, using PROC MIXED.

Advancement of northern red oak to the expanded leaf stage occurred earlier when compared to white oak (Table 3). Duration phases between phenological events were, however, similar for the two oak species (Table 4), with the only exception in 2006 when the duration of phase 2 lasted a greater number of days on white oak than on northern red oak at the Arboretum. Development of leaves on northern red oak trees was mainly synchronous across the canopy in both years at all sites. There was greater occurrence of asynchronous development of white oak across two sites in 2007, which could be related to the fluctuating temperatures during the observational period that year.

Table 4. Effect of four-way location, species, duration phase, and year interactions on duration (in number of days) between the $50 \%$ events of white and northern red oak species. Each location is analyzed separately.

\begin{tabular}{|c|c|c|c|c|c|}
\hline \multirow{3}{*}{ Location } & \multirow{3}{*}{ Species } & \multicolumn{2}{|c|}{ Duration Phase $1^{\text {a }}$} & \multicolumn{2}{|c|}{ Duration Phase 2} \\
\hline & & \multicolumn{4}{|c|}{ No. of d } \\
\hline & & 2006 & 2007 & 2006 & 2007 \\
\hline \multirow{2}{*}{ Arboretum } & Red & $5.3 \mathrm{~d}^{\mathbf{b}}$ & $14.8 \mathrm{a}-\mathrm{c}$ & $13.8 \mathrm{c}$ & $11.8 \mathrm{c}$ \\
\hline & White & $2.8 \mathrm{~d}$ & $30.8 \mathrm{a}$ & $20.3 \mathrm{ab}$ & $14.8 \mathrm{bc}$ \\
\hline \multirow{2}{*}{ Crystal Lake } & Red & $4.2 \mathrm{e}$ & $25.4 \mathrm{ab}$ & $21.4 \mathrm{bc}$ & $12.2 \mathrm{~d}$ \\
\hline & White & $4.8 \mathrm{e}$ & $28.6 \mathrm{a}$ & $17.6 \mathrm{c}$ & $11.7 \mathrm{~d}$ \\
\hline \multirow{2}{*}{ Illini Grove } & Red & $3.7 \mathrm{c}$ & $15.7 \mathrm{ab}$ & $18.3 \mathrm{a}$ & $12.5 \mathrm{~b}$ \\
\hline & White & $3.0 \mathrm{c}$ & $18.5 \mathrm{ab}$ & $19.0 \mathrm{a}$ & $13.7 \mathrm{~b}$ \\
\hline
\end{tabular}

a Duration phase 1 (swollen buds to leaf unfolding), and duration phase 2 (leaf unfolding to expanded leaf stage). ${ }^{\mathbf{b}}$ Means with the same letter across and down all columns, for each location, are not significantly different at $p \leq 0.05$ using PROC MIXED.

Phenological leaf development of red and white oak was positively and significantly correlated with growing degree days and day length (Table 5). Growth-climate correlations were strongest during May-July periods for four oak species (Quercus spp.) at sites distributed across central and eastern North America [26]. In temperate and boreal zones, timing of leaf phenological events has been correlated to temperature and photoperiod, with many models using these parameters to predict leaf onset [27]. Significant correlations were found between spring temperatures and leaf unfolding in sessile oak (Quercus petraea (Matt.) Liebl.) [27]. A strong correlation was found between sum of 
growing degree days and leaf and shoot growth in a temperate tree species, Chilean hazelnut (Gevuina avellana Mol) [28], between day length and leaf phenology in the tropical species Ficus obtusifolia [29], and between leaf phenology of trees in the Atlantic forests and day length and temperatures [30]. The correlation of the expanded leaf stage development and rainfall was not as strong in 2007. A correlation between rainfall and growth development varied between species in dry tropical forest in southeast Brazil [31].

Table 5. Correlation between different growth phases of white and red oak species with cumulative growing degree days, cumulative rainfall, and day length.

\begin{tabular}{|c|c|c|c|c|c|}
\hline \multirow{2}{*}{ Species } & \multirow{2}{*}{ Year } & \multirow{2}{*}{ Growth Stage } & Growing Degree Days & Rainfall & Day length \\
\hline & & & \multicolumn{3}{|c|}{$\mathbf{r}(\mathbf{p})$} \\
\hline \multirow{3}{*}{ Red } & \multirow{3}{*}{2006} & Swollen bud & $0.96(<0.0001)$ & $0.92(<0.0001)$ & $1.0(<0.0001)$ \\
\hline & & Leaf unfolding & $0.99(<0.0001)$ & $0.95(0.0140)$ & $1.0(0.0001)$ \\
\hline & & Expanded leaf & $1.0(<0.0001)$ & $0.85(<0.0001)$ & $1.0(<0.0001)$ \\
\hline \multirow{3}{*}{ Red } & \multirow{3}{*}{2007} & Swollen bud & $0.97(<0.0001)$ & $0.95(<0.0001)$ & $1.0(<0.0001)$ \\
\hline & & Leaf unfolding & $0.93(<0.0001)$ & $0.88(<0.0001)$ & $1.0(<0.0001)$ \\
\hline & & Expanded leaf & $1.0(<0.0001)$ & $0.49(0.0728)$ & $1.0(<0.0001)$ \\
\hline \multirow{3}{*}{ White } & \multirow{3}{*}{2006} & Swollen bud & $0.96(<0.0001)$ & $0.94(<0.0001)$ & $1.0(<0.0001)$ \\
\hline & & Leaf unfolding & $1.0(0.0015)$ & $0.78(0.2254)$ & $1.0(0.0029)$ \\
\hline & & Expanded leaf & $1.0(<0.0001)$ & $0.89(<0.0001)$ & $1.0(<0.0001)$ \\
\hline \multirow{3}{*}{ White } & \multirow{3}{*}{2007} & Swollen bud & $0.96(<0.0001)$ & $0.93(<0.0001)$ & $1.0(<0.0001)$ \\
\hline & & Leaf unfolding & $0.95(<0.0001)$ & $0.95(<0.0001)$ & $1.0(<0.0001)$ \\
\hline & & Expanded leaf & $1.0(<0.0001)$ & $0.61(0.0212)$ & $1.0(<0.0001)$ \\
\hline
\end{tabular}

\section{Conclusions}

In this study, we wanted to determine if leaf phenology could be linked to occurrence of leaf tatters in the landscape. Although leaf tatters was not found in any of our subject trees, our observations indicate that earlier emergence of red oak in the landscape may play a role in preventing tatters. Other factors such as environment and species distribution in the landscape could be influential in explaining the occurrence of leaf tatters on white oak. For example, under wet soil conditions, pre-emergence herbicide applications may not be possible and the timing of herbicides is delayed. However, oak leaf development would continue to advance during that time period, and trees might become more tolerant to the herbicides as the leaf growth stage advances. It is possible that white oaks are more prevalent along the farm margins resulting in a more common occurrence of leaf tatters in the landscape. To gain better understanding of the correlation between leaf phenological differences of the two species, and leaf tatters occurrence in the landscape, a multi-year phenology study of oaks at multiple sites across the Midwestern States would be required. Conducting such a study would be very challenging. At each of these sites, the main challenge lies in identifying suitable pairs of white and northern red oaks to form adequate replicates. Multiple observers would also be needed to observe phenological development at various locations. 


\section{Acknowledgments}

This study was partly funded by the USDA Forest Service Evaluation Monitoring Program under Award Numbers AG FS 04-DG-11244225-247 and AG FS 06-DG-11244225-117. The authors thank Carol Augspurger, John Edgington and Gary Kling for suggestions to the study, and the manuscript.

\section{Author Contributions}

Jayesh Samtani planned and executed the study, which included field observations, data analysis, and writing. Jim Appleby and John Masiunas helped guide the field study. John Masiunas garnered funding for the study, and helped with manuscript writing.

\section{Conflicts of interest}

The authors declare no conflict of interest.

\section{References}

1. Samtani, J.B.; Masiunas, J.B.; Appleby, J.E. Injury on white oak seedlings from herbicide exposure simulating drift. HortScience 2008, 43, 2076-2080.

2. Samtani, J.B.; Masiunas, J.B.; Appleby, J.E. White oak and northern red oak leaf injury from exposure to chloroacetanilide herbicides. HortScience 2010, 45, 696-700.

3. Böger, P.; Matthes, B.; Schmalfuß, J. Towards the primary target of chloroacetamides-New findings pave the way. Pest Manag. Sci. 2000, 56, 497-508.

4. Von Wettstein-Knowles, P. Biosynthesis and genetics of waxes. In Waxes: Chemistry, Molecular Biology and Functions; Hamilton, R.J., Ed.; Oily Press: Dundee, Scotland, UK, 1995; pp. 91-130.

5. Post-Beittenmiller, D. Biochemistry and molecular biology of wax production in plants. Annu. Rev. Plant Physiol. Plant Mol. Biol. 1996, 47, 405-430.

6. Heide, O.M. Daylength and thermal time responses of budburst during dormancy release in some northern deciduous trees. Phys. Plant. 1993, 88, 531-540.

7. Correia, O.A.; Martins A.C.; Catarino, F.M. Comparative phenology and seasonal foliar nitrogen variation in Mediterranean species of Portugal. Ecol. Mediterr. 1992, 8, 7-18.

8. Rathcke, B.; Lacey, E.P. Phenological patterns of terrestrial plants. Annu. Rev. Ecol. Syst. 1985, 16, 179-214.

9. Gill, D.S.; Amthor, J.S.; Bormann, F.H. Leaf phenology, photosynthesis, and the persistence of saplings and shrubs in a mature northern hardwood forest. Tree Physiol. 1998, 18, 281-289.

10. Rossi, B.E.; Debandi, G.O.; Peralta, I.E.; Palle, E.M. Comparative phenology and floral patterns in Larrea species (Zygophyllaceae) in the Monte desert (Mendoza, Argentina). J. Arid Environ. 1999, 43, 213-226.

11. Ahlgren, C.E. Phenological observations of nineteen native tree species in northeastern Minnesota. Ecology 1957, 38, 622-628.

12. Senn, J.; Hanhimäki, S.; Haukioja, E. Among-tree variation in leaf phenology and morphology and its correlation with insect performance in the mountain birch. Oikos 1992, 63, 215-222. 
13. Ne'eman, G. Variation in leaf phenology and habit in Quercus ithaburensis, a Mediterranean deciduous tree. J. Ecol. 1993, 81, 627-634.

14. Yacine, A.; Lumaret, R. Spatial distribution of genotypes in a population of holm oak (Quercus ilex L.), gene flow and mating system. Genet. Sel. Evol. 1988, 20, 181-198.

15. Crawley, M.J.; Akhteruzzaman, M. Individual variation in the phenology of oak trees and its consequences for herbivorous insects. Funct. Ecol. 1988, 2, 409-415.

16. Van Schaik, C.P.; Terborgh, J.W.; Wright, S.J. The phenology of tropical forests: Adaptive significance and consequences for primary consumers. Annu. Rev. of Ecol. and Syst. 1993, 24, 353-377.

17. Williams, R.J.; Myers, B. A.; Muller, W. J.; Duff, G.A.; Eamus, D. Leaf phenology of woody species in a north Australian tropical savanna. Ecology 1997, 78, 2542-2558.

18. Bullock, S.H.; Solís-Magallanes, J.A. Phenology of canopy trees of a tropical deciduous forest in Mexico. Biotropica 1990, 22, 22-35.

19. United States Department of Agriculture. Soil Web Survey. Available online: http://websoilsurvey.sc.egov.usda.gov/App/HomePage.htm (accessed on 25 August 2015).

20. Chuine, I.; Cour, P. Climatic determinants of budburst seasonality in four temperate-zone tree species. New Phytol. 1999, 143, 339-349.

21. Saxton, A.M. A macro for converting mean separation output to letter groupings in Proc Mixed. In Proceedings of The 23rd SAS User's Group International, SAS Institute, Cary, NC, USA, 1998. pp. 1243-1246.

22. Fritts, H.C. The relation of radial growth to maximum and minimum temperatures in three tree species. Ecology 1959, 40, 261-265.

23. Tardif, J.C.; Conciatori, F. A comparison of ring-width and event-year chronologies derived from white oak (Quercus alba) and northern red oak (Quercus rubra), southwest Quebec, Canada. Dendrochronologia 2006, 23, 133-138.

24. Pan, C.; Tajchman, S.J.; Kochenderfer, J.N. Dendroclimatological analysis of major species of the central Appalachians. Forest Ecol. Manage. 1997, 98, 77-87.

25. Illinois State Water Survey. Local Climatological Data, Champaign-Urbana, IL-118740, March through June 2006 and 2007. Available online: http://www.sws.uiuc.edu/atmos/statecli/ (accessed on 27 July 2015).

26. LeBlanc, D.C.; Stahle, D.W. Radial growth responses of four oak species to climate in eastern and central north America. Can. Journal. For. Res. 2015, 45, 793-804.

27. Vitasse, Y.; Delzon, S.; Dufrêne, E.; Pontailler, J.-Y.; Louvet, J.-M.; Kremer, A.; Michalet, R. Leaf phenology sensitivity to temperature in European trees: Do within-species populations exhibit similar responses? Agric. and Forest Meteorol. 2009, 149, 735-744.

28. Medel, G.; Medel, F.; Huber, A.; McConchie, C. Phenological development and growing degree days in Gevuina avellana Mol. Acta. Hortic. 2014, 1052, 355-361.

29. Ballestrini, C.; Tezara, W.; Herrera, A. Environmental drivers of leaf phenology in trees of the tropical species Ficus obtusifolia. Braz. J. Plant Physiol. 2011, 23, 113-122.

30. Patrícia, L.; Morellato, C.; Talora, D.C.; Takahasi, A.; Bencke, C.C.; Romera, E.C.; Zipparro, V.B. Phenology of Atlantic rain forest trees: A comparative study. Biotropica 2000, 32, 811-823. 
31. Grogan, J.; Schulze, M. The impact of annual and seasonal rainfall patterns on growth and phenology of emergent tree species in southeastern Amazonia, Brazil. Biotropica 2012, 44, 331-340.

(C) 2015 by the authors; licensee MDPI, Basel, Switzerland. This article is an open access article distributed under the terms and conditions of the Creative Commons Attribution license (http://creativecommons.org/licenses/by/4.0/). 